\title{
Increasing physical activity by Gamification among $\cong$ Brazilian high school students: a pilot study
}

\author{
Aumento da atividade física por gamificação em estudantes brasileiros do ensino \\ médio: um estudo piloto
}

\section{AUTHOR'S \\ Eduardo Lucia Caputo ${ }^{1}$ (D) \\ Natan Feter ${ }^{1}$ (D) \\ Ricardo $\mathrm{Alt}^{2}$ (I) \\ Jayne Santos Leite ${ }^{3}$ (D) \\ Alysson Nogueira Rodrigues ${ }^{4}$ (D) \\ Samuel Carvalho Dumith ${ }^{5}$ (D) \\ Marcelo Cozzensa da Silva ${ }^{1}$ (D) \\ 1 Universidade Federal de Pelotas, Programa de Pós-Graduação em Educação Física, Pelotas, Rio Grande do Sul, Brasil. \\ 2 Universidade Federal de Pelotas, Programa de Pós-Graduação em Epidemiologia, Pelotas, Rio Grande do Sul, Brasil. \\ 3 Universidade Federal do Rio Grande do Sul, Programa de Pós-Graduação em Cardiologia e Ciências Cardiovasculares, Porto Alegre, Rio Grande do Sul, Brasil. \\ 4 Universidade Federal de Pelotas, Faculdade de Ciências da Computação, Pelotas, Rio Grande do Sul, Brasil. \\ 5 Universidade Federal do Rio Grande, Programa de Pós-Graduação em Saúde Pública, Rio Grande, Rio Grande do Sul, Brasil.}

\section{CORRESPONDING}

\section{Eduardo L Caputo}

caputoeduardo@yahoo.com.br

Rua Luis de Camões, n. 625. Pelotas, Rio

Grande do Sul, Brazil.

ZIP CODE: 96055-630.

DOI

10.12820/rbafs.26e0230

\begin{abstract}
This pilot study aimed to evaluate the effectiveness of a Gamification-based intervention on physical activity levels of High School students. This quasi-experimental study was conducted in two federal high schools in Southern Brazil. One class from each school was selected to be either intervention (INT) or control (CON) group. Experiment duration was two weeks, and both groups downloaded My Active Life app. INT group $(n=69)$ participants received daily app alerts with messages of encouragement to practice physical activity. They also received a score based on the percentage of goal achieved. CON group $(n=35)$ only had access to total number of steps per day. INT group showed a lower decrease in physical activity at school compared to CON group $(p=0.024)$. No effect of intervention was observed in physical activity out of school $(p=0.911)$. Gamification-based intervention prevented a decrease in physical activity at school among male $(\mathrm{F}=10.680 ; \mathrm{p}=0.004)$, students at first half of high school $(\mathrm{F}=12.668 ; \mathrm{p}=0.002)$, and adequate body mass index $(\mathrm{F}=4.640 ; \mathrm{p}=0.037)$, and with lower perception of barriers to physical activity $(F=5.437 ; \mathrm{p}=0.024)$. Although we did not observe an increase in physical activity at school, gamification-based intervention may mitigate its decrease among adolescents.
\end{abstract}

Keywords: Smartphone; Physical activity; adolescents.

RESUMO

Este estudo piloto teve como objetivo avaliar a eficácia de uma intervenção baseada em gamificação nos niveis de atividade física de alunos do ensino médio. Este estudo quase-experimental foi realizado em duas escolas federais de ensino médio no sul do Brasil. Uma turma de cada escola foi selecionada para ser um grupo de intervenção (INT) ou controle (CON). A duração do experimento foi de duas semanas, e ambos os grupos baixaram o aplicativo My Active Life. Os participantes do grupo INT $(n=69)$ receberam alertas diários no app com mensagens de incentivo à prática de atividade física. Eles também receberam uma pontuação com base no percentual de meta alcançada. O grupo $C O N(n=35)$ só teve acesso ao número total de passos por dia. O grupo INT apresentou menor diminuição da atividade física na escola em comparação ao grupo CON $(p=0,024)$. Nenhum efeito da intervenção foi observado na atividade física fora da escola $(p=0,911) . A$ intervenção baseada na gamificação evitou uma diminuição da atividade física na escola entre meninos ( $F$ $=10,680 ; p=0,004)$, alunos na primeira metade do ensino médio $(F=12,668 ; p=0,002)$ e indice de massa corporal adequado $(F=4,640 ; p=0,037)$, e com menor percepção de barreiras à atividade física $(F=5,437$; $p=0,024)$. Embora não tenhamos observado aumento da atividade física na escola, a intervenção baseada na gamificação pode atenuar sua diminuição entre os adolescentes.

Palavras-chave: Smartphone; Atividade física; adolescentes.

\section{(c) BY}

This work is licensed under a Creative Commons Attribution 4.0 International License.

\section{Introduction}

The high rates of physical inactivity are associated with an increased prevalence of chronic diseases, such as obesity, diabetes and depression, generating high costs for public health systems ${ }^{1,2}$. Adolescence is a crucial period of an individual's lifetime, since most behaviors adopted at this stage of life might remain in adulthood, such as physical activity. Being physically active from early ages through adulthood may decrease the risk of several health impairments, such as obesity, cancer, etc ${ }^{3,4}$.

Smartphones represented a shift in daily life with its vast list of features and applications (apps), making its use constant, regardless of time and place ${ }^{5,6}$. Although screen time is associated with sedentary behav- 
ior in adolescents ${ }^{7,8}$, these devices are important allies in accessing information, and can be useful in carrying out interventions for a healthy lifestyle ${ }^{9}$.

Gamification is defined as the use of elements of virtual games, in contexts in which they would not be related. In general, virtual games are associated with negative factors, such as addiction, for example. The idea of gamification is to make use of these resources as a way of intervention in order to modify people's behavior ${ }^{10,11}$. Exergames ${ }^{12}$, geo-centric games (Pokémon Go $)^{13}$ and app interventions ${ }^{14,15}$, are some examples of Gamification strategies to increase physical activity.

Technology has already been incorporated in adolescents' daily life, making the use of gamified intervention an important approach to change and motivate health behaviors in this population. Games might be powerful tool in educational setting, and there is good evidence showing its beneficial effects in nutritional and sexual behavior, for example ${ }^{3,4}$. App interventions using Gamification demonstrated a positive effect, both in relation to days of physical activity and steps per day ${ }^{14,15}$. Regarding this issue there are still some gaps in literature as follows: a) identify populations, and their characteristics, that can benefit from this type of intervention; b) how these interventions can adapt to subject's characteristics; and c) what is the best way to use them to change behavior ${ }^{16}$.

In this context, it is important to evaluate the functionality of devices, such as smartphones, as a way of intervention aiming to change physical activity patterns in different populations. This pilot study aimed to evaluate the effectiveness of a Gamification-based intervention on physical activity levels of High School students in Brazil.

\section{Methods}

A 2-week quasi-experimental study was conducted in two Federal Public High Schools in the cities of Pelotas and Rio Grande, Rio Grande do Sul, Brazil. These two cities are $60 \mathrm{~km}$ apart. Schools of different cities were choosed to avoid contamination. The schools were selected by convenience, where the school located in Rio Grande being the control group.

Students aged between 14 and 18 were invited to take part in the study. In each school, a class from each year was randomly selected to take part in the study. Thus, three classes from each school in their respective cities participated in study.

To take part in the study participants had to: a) be enrolled in school, and attending classes regularly; b) have a mobile device with Android operational system; and c) aged between 14 and 18 years.

Physical activity in school and out of school, was assessed through questions from the Brazilian National School Survey (PENSE), both pre- and post-intervention period ${ }^{17}$. Physical activity at school was assessed based on number of days and time per day spent in physical activities at school. Out of school physical activity was measured based on number of days and duration of leisure-time and commuting physical activity over the seven days prior the survey (Table 1).

Table 1 - Physical activity in school and out of school questions. Brazilian National School Survey (PENSE) ${ }^{17}$

\begin{tabular}{|c|c|c|}
\hline & Days & Time \\
\hline $\begin{array}{l}\text { Physical } \\
\text { Activity at } \\
\text { school }\end{array}$ & $\begin{array}{l}\text { In the last } 7 \text { days, how many } \\
\text { days did you have physical } \\
\text { education classes at school? }\end{array}$ & $\begin{array}{l}\text { In the last } 7 \text { days, for } \\
\text { how much time a day did } \\
\text { you do physical activity } \\
\text { or sport during physical } \\
\text { education classes at } \\
\text { school? }\end{array}$ \\
\hline \multicolumn{3}{|c|}{ Physical Activity out of school } \\
\hline Leisure-time & $\begin{array}{l}\text { In the last } 7 \text { days, not } \\
\text { counting the school's physical } \\
\text { education classes, how many } \\
\text { days did you practice any } \\
\text { physical activity such as } \\
\text { sports, dance, gymnastics, } \\
\text { weight training, fights or } \\
\text { other activity? }\end{array}$ & $\begin{array}{l}\text { Usually, for how long a } \\
\text { day do these activities } \\
\text { last? }\end{array}$ \\
\hline Commuting & $\begin{array}{l}\text { In the last } 7 \text { days, how many } \\
\text { days did you go or come back } \\
\text { from school on foot or by } \\
\text { bicycle? }\end{array}$ & $\begin{array}{l}\text { When you go or come } \\
\text { back from school on foot } \\
\text { or by bicycle, how much } \\
\text { time do you spend? }\end{array}$ \\
\hline
\end{tabular}

Covariates were assessed pre- and post-intervention period through a questionnaire. Gender (male and female), years in school; skin color (white, black, other), age (years), physical activity barriers ${ }^{18}$, and self-reported height $(\mathrm{cm})$ and weight $(\mathrm{Kg})$ were assessed ${ }^{19,20}$. Body Mass Index (BMI) was calculated using the following formula: Body Mass (kg)/ Height ${ }^{2}(\mathrm{~m})$.

Experiment duration was two weeks, where three meetings with participants were held. In the first visit at schools, study aims were explained and informed consent form was delivered to each participant. In the second visit, participants who provided the consent form signed by a parent or legal guardian (participants aged $<18$ ), or by themselves (participants aged 18) were signed up. After this stage one researcher gave instructions to the participants on how to download, install and use the app. At the last meeting, researchers informed the end of the research period, in addition 
to thanking participants for their participation during the two weeks of data collection. In addition, the participants were told that they could keep using the app without any commitment to the research (e.g., concern with energy consumption, sending data).

My Active Life app was used in this study. It was developed in the Computer Science graduation course at the Federal University of Pelotas, Brazil. The app is compatible with the Android operational system, and it was downloaded free of charge (https://play.google.com/ store/apps/details?id=com. pyramitec.myactivelife). Participants in intervention group received app alerts, in a daily basis, with messages of encouragement to practice physical activity. The goal was to perform 10,000 steps per day in each day during the intervention period. A score was generated for each goal achieved, according to the stipulated physical activity goal. Participants were rewarded in points (positive feedback) through the following system: percentage of goal achieved $=$ number of points. For example: if a participant achieved 5,000 steps, he or she would score 50.

At the beginning of each week, participants received a message recalling how they performed in the past week, and the importance of reaching physical activity goals. The general classification from the class was also available weekly, so students could compare their scores with others from the same class. The control group only had access to total number of steps per day practiced. Download of data, as well as the messages sent, were conducted together with app developer. Data were monitored in a daily basis, for both groups, through app online system. This strategy allowed a control over data and the app use by participants. The study was approved by the Institutional Ethics Board from the Medical Faculty of the Federal University of Rio Grande (Registration number: 03350818.5.3001.5324).

Continuous and categorical data were described as mean ( \pm standard error of mean [SEM]) and absolute (relative, \%) values, respectively. Normal distribution was tested by Shapiro-Wilk test, and homoscedasticity by Levene's test. Difference between groups at baseline were tested by independent-sample $\mathrm{T}$ test, Wilcoxon test, chi-squared, and Fisher's exact test, as appropriated.

In order to verify the effect of gamification-based intervention, repeated-measures ANCOVA with posthoc of Bonferroni was conducted to identify differences between the groups. Analyses were adjusted for variables that presented difference at baseline between groups (age, BMI, and physical education class per week). Subgroup analyses were performed with sample stratified by sex, BMI, time in school, sitting time tertile and barriers to physical activity given the effect of such factors in physical activity level. Analyzes were conducted using SPSS version 26.0 and Graph Prism version 8. Level of significance adopted was $\mathrm{p}<0.05$.

\section{Results}

One-hundred and three participants were included at baseline. Students from intervention group were older $(\mathrm{p}<0.001)$, they had more hours of physical education class per week $(\mathrm{p}<0.001)$ and lower sitting time at school ( $p<0.001)$ compared to control group. However, no difference in physical activity level out of school was observed between groups in baseline (Table 2). Overall, participants accessed the app for an average of

Table 2 - Baseline characteristics of adolescents participating in the study. Pelotas, Rio Grande do Sul, Brazil ( $\mathrm{n}=104)$.

\begin{tabular}{|c|c|c|c|}
\hline & $\begin{array}{l}\text { Control } \\
(\mathrm{n}=35)\end{array}$ & $\begin{array}{c}\text { Intervention } \\
\quad(\mathrm{n}=69)\end{array}$ & $\mathrm{p}$ value \\
\hline Age, years & $16.6(0.1)$ & $17.4(0.1)$ & $<0.001^{\mathrm{a}}$ \\
\hline Sex, n (\%) & & & $0.053^{\mathrm{b}}$ \\
\hline Male & $18(51.4)$ & $22(31.9)$ & \\
\hline Female & $17(48.6)$ & $47(68.1)$ & \\
\hline Skin color & & & $0.655^{\mathrm{b}}$ \\
\hline White & $29(85.3)$ & $61(88.4)$ & \\
\hline Black & $5(14.7)$ & $8(11.6)$ & \\
\hline Time in school, months & $25.2(1.5)$ & $30.5(2.0)$ & $0.087^{\mathrm{a}}$ \\
\hline BMI, n (\%) & & & $0.049^{c}$ \\
\hline Normal & $25(71.4)$ & $60(86.9)$ & \\
\hline Overweight & $10(28.6)$ & $9(13.1)$ & \\
\hline \multicolumn{4}{|c|}{ Parent's years of schooling, years } \\
\hline Mother & $4.7(0.3)$ & $4.1(0.2)$ & $0.053^{\mathrm{a}}$ \\
\hline Father & $4.4(0.3)$ & $4.2(0.2)$ & $0.487^{\mathrm{a}}$ \\
\hline $\begin{array}{l}\text { Physical education, minutes } \\
\text { per week* }^{*}\end{array}$ & $120(60-220)$ & $135(135-360)$ & $<0.001^{\mathrm{d}}$ \\
\hline \multicolumn{4}{|c|}{ Physical activity, minutes per week* } \\
\hline Travel & $40(0-100)$ & $0(0-75)$ & $0.088^{\mathrm{d}}$ \\
\hline Leisure & $60(0-180)$ & $120(0-270)$ & $0.425^{\mathrm{d}}$ \\
\hline \multicolumn{3}{|c|}{ Attitudes toward physical activity } & $0.028^{c}$ \\
\hline $\begin{array}{l}\text { Would not do any } \\
\text { physical activity }\end{array}$ & $0(0)$ & $4(5.8)$ & \\
\hline Would do PA & $27(81.8)$ & $38(55.1)$ & \\
\hline Already do PA & $6(18.2)$ & $27(39.1)$ & \\
\hline \multicolumn{4}{|c|}{ Sitting time, minutes per week* } \\
\hline Weekdays (no school) & $180(120-240)$ & $240(120-480)$ & $0.161^{\mathrm{d}}$ \\
\hline Weekend (no school) & $310(180-600)$ & $300(120-600)$ & $0.332^{\mathrm{d}}$ \\
\hline At school & $300(240-420)$ & $240(60-270)$ & $<0.001^{\mathrm{d}}$ \\
\hline Barriers for $\mathrm{PA}$, number & $5.2(2.3)$ & $5.1(2.6)$ & $0.793^{\mathrm{a}}$ \\
\hline
\end{tabular}

* Values expressed in median and interquartile range; $\mathrm{a}=\mathrm{T}$ test; $\mathrm{b}=$ Chi-squared test; $\mathrm{c}=$ Fisher's exact; $\mathrm{d}=$ Wilcoxon test 
92 minutes, being $87 \mathrm{~min}$ for light and 5 for moderate physical activities. Figure 1 reports that intervention group had a lower decrease in physical activity time at school compared to control group $(F(1,48)=5.437$; $p$ $=0.024)$. However, no effect of intervention was observed in minutes of physical activity out of school ( $F(1$, 48) $=0.013 ; p=0.911)$.

Gamification-based intervention prevented a decrease in physical activity at school among male ( $\mathrm{F}(1$, 22) $=10.680 ; p=0.004)$, students at first half of high school $(\mathrm{F}(1,21)=12.668 ; \mathrm{p}=0.002)$, and normal BMI

A

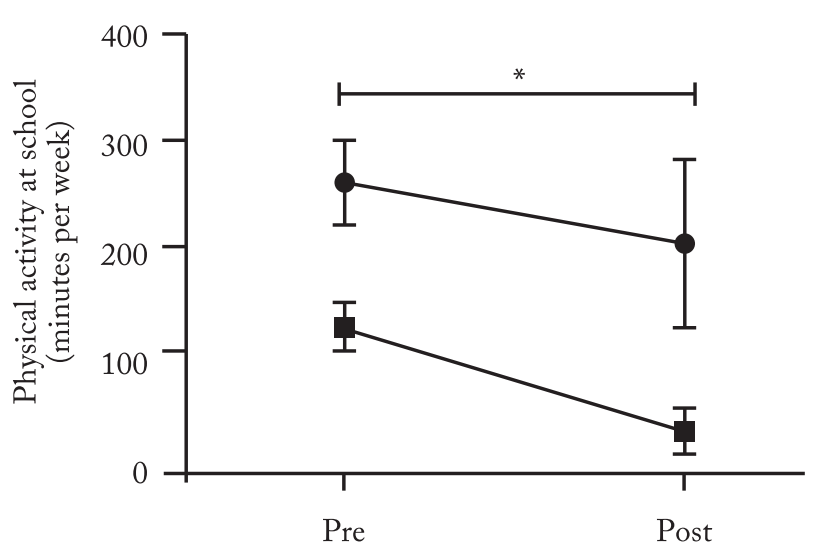

$(\mathrm{F}(1,41)=4.640 ; \mathrm{p}=0.037)$, and with lower perception of barriers to physical activity $(\mathrm{F}(1,48)=5.437$; $\mathrm{p}=0.024)$ - Table 3. On the other hand, no changes were observed in physical activity out of school among sample from both groups (Table 4).

\section{Discussion}

Physical activity at school in intervention group decreased less than in control group after intervention. However, there was no significant effect of intervention on physical activity out of school. Male partici-

B

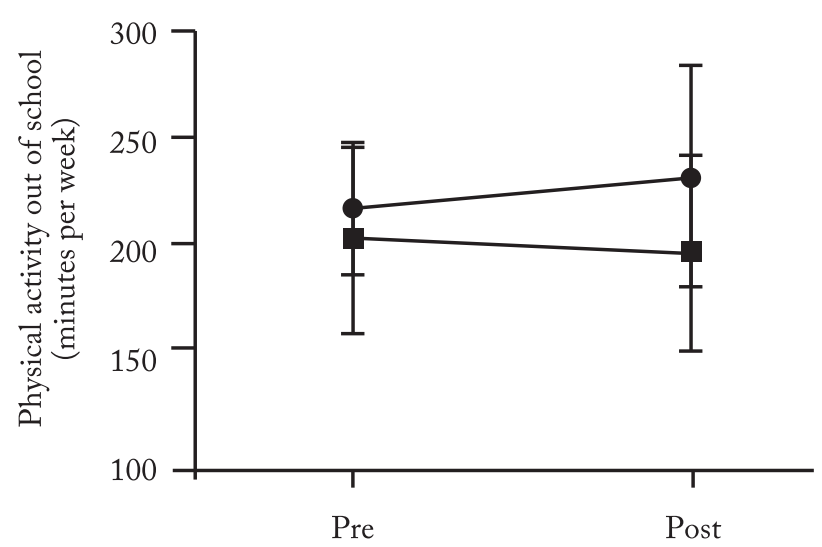

Figure 1 - Physical activity at (A) and out of (B) school pre- and post-intervention.

* Indicates significant group $\mathrm{x}$ time interaction.

Table 3 - Physical activity (minutes per week) at school pre- and post-intervention stratified by subgroups. Pelotas, Rio Grande do Sul, Brazil $(\mathrm{n}=51)$.

\begin{tabular}{|c|c|c|c|c|c|c|c|c|c|}
\hline & \multicolumn{3}{|c|}{ Control $(\mathrm{n}=20)$} & \multicolumn{3}{|c|}{ Intervention $(\mathrm{n}=31)$} & \multirow{2}{*}{$\begin{array}{l}\text { Group } \\
\text { p value }\end{array}$} & \multirow{2}{*}{$\begin{array}{c}\text { Time } \\
\text { p value }\end{array}$} & \multirow{2}{*}{$\begin{array}{c}\text { Group x time } \\
\text { p value }\end{array}$} \\
\hline & Pre & Post & $\mathrm{p}$ value & Pre & Post & $\mathrm{p}$ value & & & \\
\hline \multicolumn{10}{|l|}{ Sex, n (\%) } \\
\hline Male & $131.1(32.8)$ & $16.2(10.0)$ & 0.012 & $220.9(35.9)$ & $76.4(30.8)$ & 0.125 & 0.272 & 0.004 & 0.400 \\
\hline Female & $138.2(27.6)$ & $85.7(56.9)$ & 0.659 & $286.9(50.9)$ & $285.7(116.2)$ & 0.648 & 0.120 & 0.680 & 0.909 \\
\hline \multicolumn{10}{|l|}{ Time in school } \\
\hline 2 years or less & $135.2(28.8)$ & $54(27.8)$ & 0.023 & $253.6(48.7)$ & 333.7 (192.3) & 0.180 & 0.081 & 0.002 & 0.015 \\
\hline More than 2 years & $145.8(35.7)$ & $0.0(0.0)$ & 0.125 & $281.1(56.0)$ & $133.7(32.9)$ & 0.210 & 0.134 & 0.159 & 0.922 \\
\hline \multicolumn{10}{|l|}{ BMI, n (\%) } \\
\hline Normal & $133.9(27.3)$ & $40.7(26.2)$ & 0.006 & $277.4(41.4)$ & $232.4(88.0)$ & 0.09 & 0.047 & 0.037 & 0.822 \\
\hline Overweight & $139.0(42.0)$ & $60.0(60.0)$ & $>0.999$ & $205.0(67.5)$ & $45.0(45.0)$ & 0.50 & 0.940 & 0.378 & 0.809 \\
\hline \multicolumn{10}{|c|}{ Sitting time, percentile } \\
\hline 1 st & $90.0(19.6)$ & $180.0(180.0)$ & $>0.999$ & $246.7(52.5)$ & $244.6(162.2)$ & 0.34 & 0.779 & 0.637 & 0.920 \\
\hline 2nd & $125.0(31.7)$ & $36.7(26.3)$ & 0.125 & $338.7(97.1)$ & $146.0(51.9)$ & 0.29 & 0.327 & 0.168 & 0.355 \\
\hline $3 r d$ & $127.5(32.2)$ & $20.0(20.0)$ & 0.063 & $231.0(41.4)$ & $238.9(142.5)$ & 0.45 & 0.314 & 0.418 & 0.296 \\
\hline \multicolumn{10}{|c|}{ Barriers for physical activity } \\
\hline 5 or less & $151.7(36.8)$ & $48.0(36.7)$ & 0.039 & $237.5(53.7)$ & $264.7(132.3)$ & 0.58 & 0.092 & 0.071 & 0.487 \\
\hline 6 or more & $124.3(23.1)$ & $41.3(29.4)$ & 0.13 & $301.0(53.0)$ & $173.7(96.1)$ & 0.11 & 0.583 & 0.890 & 0.979 \\
\hline
\end{tabular}


Table 4 - Physical activity (minutes per week) out of school pre- and post-intervention stratified by subgroups. Pelotas, Rio Grande do Sul, Brazil $(\mathrm{n}=51)$.

\begin{tabular}{|c|c|c|c|c|c|c|c|c|c|}
\hline & \multicolumn{3}{|c|}{ Control $(\mathrm{n}=20)$} & \multicolumn{3}{|c|}{ Intervention $(\mathrm{n}=31)$} & \multirow{2}{*}{$\begin{array}{l}\text { Group } \\
\mathrm{p} \text { value }\end{array}$} & \multirow{2}{*}{$\begin{array}{l}\text { Time } \\
\text { p value }\end{array}$} & \multirow{2}{*}{$\begin{array}{l}\text { Group } \mathrm{x} \text { time } \\
\mathrm{p} \text { value }\end{array}$} \\
\hline & Pre & Post & $\mathrm{p}$ value & Pre & Post & $p$ value & & & \\
\hline \multicolumn{10}{|l|}{ Sex, n (\%) } \\
\hline Male & $151.4(37.2)$ & $150.4(45.4)$ & 0.344 & $112.1(25.7)$ & $81.8(29.0)$ & $>0.999$ & 0.079 & 0.595 & 0.547 \\
\hline Female & $268.0(78.9)$ & $291.4(89.1)$ & 0.219 & $271.4(40.6)$ & $318.5(70.2)$ & 0.143 & 0.538 & 0.479 & 0.151 \\
\hline \multicolumn{10}{|l|}{ Time in school } \\
\hline 2 years or less & $164.4(33.5)$ & $250.0(106.5)$ & $>0.999$ & $283.4(55.1)$ & $281.7(95.1)$ & 0.687 & 0.286 & 0.482 & 0.337 \\
\hline More than 2 years & $250.0(106.5)$ & $138.0(78.6)$ & $>0.999$ & $165.4(25.7)$ & $204.7(57.3)$ & 0.302 & 0.559 & 0.817 & 0.775 \\
\hline \multicolumn{10}{|l|}{ BMI, n (\%) } \\
\hline Normal & $200.2(44.0)$ & $178.6(56.8)$ & 0.754 & $226.7(33.4)$ & $248.0(56.9)$ & 0.167 & 0.715 & 0.558 & 0.715 \\
\hline Overweight & $230.7(111.7)$ & $286.3(71.0)$ & 0.625 & $196.7(74.7)$ & $166.7(88.2)$ & $>0.999$ & 0.323 & 0.354 & 0.582 \\
\hline \multicolumn{10}{|l|}{ Sitting time, percentile } \\
\hline 1 st & $292.5(143.3)$ & $225.0(225.0)$ & $>0.999$ & $222.4(51.3)$ & $288.5(103.0)$ & 0.727 & 0.689 & 0.446 & 0.817 \\
\hline 2 nd & $171.9(45.0)$ & $144.4(52.5)$ & 0.289 & $247.7(54.5)$ & $214.5(64.9)$ & 0.289 & 0.246 & 0.035 & 0.391 \\
\hline $3 \mathrm{rd}$ & $152.5(57.5)$ & $228.3(72.4)$ & 0.375 & $203.3(52.2)$ & $171.9(67.2)$ & $>0.999$ & 0.969 & 0.440 & 0.136 \\
\hline \multicolumn{10}{|c|}{ Barriers for physical activity } \\
\hline 5 or less & $200.8(49.0)$ & $164.0(58.7)$ & $>0.999$ & $256.0(42.5)$ & $274.4(85.7)$ & 0.267 & 0.219 & 0.638 & 0.996 \\
\hline 6 or more & $220.5(84.0)$ & $235.6(76.3)$ & $>0.999$ & $179.2(44.8)$ & $200.0(59.8)$ & $>0.999$ & 0.962 & 0.842 & 0.334 \\
\hline
\end{tabular}

pants, as well as, students at first half of high school, and with normal BMI, and with lower perception of barriers to physical activity showed lower decrease in physical activity at school. In contrast, as regards to physical activity out of school, no effects were observed for both groups.

Our data showed an intervention effect in at school, but not in out of school physical activity. On average, Brazilian schools have from 1 to 2 days of Physical Education (PE) classes. Also, Brazil is below the average of minutes of $\mathrm{PE}$ classes in comparison with other countries ${ }^{21}$ which makes also important to increase physical activity in school environment.

Overall, Brazilian adolescents reported on average 2 to 3 days of moderate and 1 to 2 days of vigorous physical activity out of school ${ }^{21}$. This is below the 60 minutes daily recommendation of physical activity for children and adolescents ${ }^{22}$. In addition, there are several barriers reported by adolescents for not being physically active outside school (e.g. lack of social support, weather, laziness $)^{23}$. This might explain the lack of an intervention effect in out of school physical activity.

Studies on adult samples have reported a positive effect of gamification-based intervention in moderate-to-vigorous physical activity ${ }^{24,25}$, average number of physical activity days ${ }^{14}$ and number of daily steps ${ }^{15}$. However, this effect is not reported in studies with ad- olescent samples ${ }^{26,27}$. A study in North Ireland, with adolescents aged 12-14 years old did not find changes in moderate-to-vigorous physical activity, in both intervention and control group ${ }^{26}$. As gamification is a new intervention approach, there are still some gaps in how adolescents are influenced by this method.

From the 104 participants enrolled in baseline, 49\% completed the post-intervention survey, being $57 \%$ in control group and $44.9 \%$ in intervention group. This is a high drop rate, when compared to other studies ${ }^{14,15,25-28}$. Corepal et al reported a low drop rate after intervention $(10 \%)^{26}$. However, this study used money and voucher reward to winners, which can explain the low drop rate. In our study, we only used game reward, and maybe this could not be enough for adolescents to keep in competition. Rewards such as trophies, vouchers and money, are more related to competition than being active, and for some people this is more important in a competitive field ${ }^{10,27,28}$. This could explain why a game reward and just competition between schools did not show an effect on physical activity outside of school. Future studies should design strategies to avoid participants dropouts through intervention.

Participants engaged in competition tend to increase physical activity. However, this may not be true in a personal level. Also, students aged 15-17 years old and were in High School. In this age competing might 
not be sufficient, making participants quit the game when they realize that wining is unlikely ${ }^{29}$. This will result in an increase in physical activity only in the first places, and could lead to a bias.

Limitations of this study should be listed. First, the high dropout rate of participants might limit the power of our analyzes. Second, the short intervention period could not be enough to change participants behavior regarding physical activity. However, physical activity is the second health topic most studied by gamification-based interventions ${ }^{9}$. Others have studied the effects of this approach in undergraduates ${ }^{24}$, adults ${ }^{25}$, community $^{14}$, and family ${ }^{15}$ based samples. However, literature presents a lack of studies on physical activity in children ${ }^{28,30}$ and adolescent population ${ }^{26,27,31}$, which demonstrates the relevance of this study. To the best of authors knowledge, this is the first study to use a physical activity gamification-based intervention in adolescents in Brazil. Future studies should design strategies aiming to avoid follow-up losses (ie making gaming more competitive, and ways to keep participant in the competition). Also, studies in other populations, such as chronic disease patients, elderly and community gamification trials should be conducted.

In conclusion, this pilot study found that a 2-week gamification-based intervention showed a small effect in physical activity performed at school. On the other hand, there was no intervention effect regarding out of school physical activity. Also, no effect of sex, time in school, BMI, siting time and barriers for physical activity was observed. Further studies using different adherence strategies, as well as, assessing physical activity directly, are needed.

\section{Conflict of interest:}

The authors declare no conflict of interest.

\section{Author's contributions}

Caputo EL and Feter N participated in the conception and writing of the manuscript, data analysis and interpretation. Rodrigues AN, Alt R and Leite JS participated in data collection and interpretation. Dumith SC and Silva MC participated in the design and final review of the manuscript.

\section{Acknowledgments}

This study was financed in part by the Coordenação de Aperfeiçoamento de Pessoal de Nível Superior - Brasil (CAPES) - Financing Code 001.

\section{References}

1. Humphreys BR, McLeod L, Ruseski JE. Physical activity and health outcomes: Evidence from Canada. Health Econ (United Kingdom). 2014;23:33-54.

2. Wicker P, Coates D, Breuer C. Physical activity and subjective well-being: the role of time. Eur. J. Public Health. 2015;25:864-8.

3. Chau MM, Burgermaster M, Mamykina L. The use of social media in nutrition interventions for adolescents and young adults-A systematic review. Int J Med Inform. 2018;120:77-91.

4. Haruna $\mathrm{H}, \mathrm{Hu} \mathrm{X}$, Chu SKW, Mellecker RR, Gabriel G, Ndekao PS. Improving Sexual Health Education Programs for Adolescent Students through Game-Based Learning and Gamification. Int $\mathrm{J}$ Environ Res Public Health. 2018;15(9):2027.

5. Kim SE, Kim JW, Jee YS. Relationship between smartphone addiction and physical activity in Chinese international students in Korea. J. Behav. Addict. 2015;4:200-5.

6. Mok JY, Choi SW, Kim DJ, Choi JS, Lee J, Ahn H, et al. Latent class analysis on internet and smartphone addiction in college students. Neuropsychiatr. Dis. Treat. 2014;10:817-27.

7. Iannotti RJ, Kogan MD, Janssen I, Boyce WF. Patterns of Adolescent Physical Activity, Screen-Based Media Use, and Positive and Negative Health Indicators in the U.S. and Canada. J. Adolesc. Health. 2009;44:493-9.

8. Iannotti RJ, Wang J. Patterns of physical activity, sedentary behavior, and diet in U.S. adolescents. J. Adolesc. Health. 2013;53:280-6.

9. Sardi L, Idri A, Fernández-Alemán JL. A systematic review of gamification in e-Health. Vol. 71, Journal of Biomedical Informatics. Academic Press Inc.; 2017. p. 31-48.

10. Cugelman B. Gamification: what it is and why it matters to digital health behavior change developers. JMIR Serious Games. 2013;1:e3.

11. Cesa GL, Manzoni GM, Bacchetta M, Castelnuovo G, Conti S, Gaggioli A, et al. Virtual reality for enhancing the cognitive behavioral treatment of obesity with binge eating disorder: Randomized controlled study with one-year followup. J Med Internet Res. 2013;15:e113.

12. Staiano AE, Calvert SL. Exergames for Physical Education Courses: Physical, Social, and Cognitive Benefits. Child Dev. Perspect. 2011;5:93-8.

13. Althoff T, White RW, Horvitz E. Influence of Pokémon Go on Physical Activity: Study and Implications. J Med Internet Res. 2016;18:e315.

14. Harris MA. The relationship between physical inactivity and mental wellbeing: Findings from a gamification-based community-wide physical activity intervention. Health Psychol. Open. 2018;5:2055102917753853.

15. Patel MS, Benjamin EJ, Volpp KG, Fox CS, Small DS, Massaro JM, et al. Effect of a game-based intervention designed to enhance social incentives to increase physical activity among families: The BE FIT randomized clinical trial. JAMA. 2017;177:1586-93.

16. Pandian JD, Gall SL, Kate MP, Silva GS, Akinyemi RO, Ovbiagele BI, et al. Prevention of stroke: a global perspective. Vol. 392, The Lancet. Lancet Publishing Group; 2018. p. 1269-78.

17. Oliveira MM, Campos MO, Andreazzi MAR de, Malta DC, Oliveira MM de, Campos MO, et al. Características da Pesquisa Nacional de Saúde do Escolar - PeNSE. Epidemiol. Serv. Saude. 2017;26:605-16. 
18. Santos MS, Reis RS, Rodriguez-Añez CR, Fermino RC. Desenvolvimento de um instrumento para avaliar barreiras para aprática de atividade física em adolescentes. Rev Bras Ativ Fís Saúde. 2009;14:76-85.

19. Fermino RC, Rech CR, Hino AA, Rodriguez Añez CR, Reis RS. Physical activity and associated factors in highschool adolescents in Southern Brazil. Rev Saude Publica. 2010;44(6):986-95.

20. Farias Júnior JC, Lopes Ada S, Mota J, Hallal PC. Physical activity practice and associated factors in adolescents in Northeastern Brazil. Rev Saude Publica. 2012 Jun;46(3):505-15.

21. Bann D, Scholes S, Fluharty M, Shure N. Adolescents' physical activity: Cross-national comparisons of levels, distributions and disparities across 52 countries. Int. J. Behav. Nutr. Phys. Act. 2019;16:1-11.

22. HHS. Physical Activity Guidelines for Americans 2 nd edition.

23. Santos MS, Hino AA, Reis RS, Rodriguez-Añez CR. Prevalência de barreiras para a prática de atividade física em adolescentes. Rev Bras Epidemiol. 2010;13(1):94-104.

24. Mo D, Xiang M, Luo M, Dong Y, Fang Y, Zhang S, et al. Using gamification and social incentives to increase physical activity and related social cognition among undergraduate students in Shanghai, China. Int. J. Environ. Res. 2019;16.

25. Edney SM, Olds TS, Ryan JC, Vandelanotte C, Plotnikoff RC, Curtis RG, et al. A Social Networking and Gamified App to Increase Physical Activity: Cluster RCT. Am. J. Prev. Med. 2020;58:e51-62.

26. Corepal R, Best P, O’Neill R, Kee F, Badham J, Dunne L, et al. A feasibility study of "The StepSmart Challenge" to promote physical activity in adolescents. Pilot Feasibility Stud. 2019;5.
27. Corepal R, Best P, Tully MA, Edwards M, Jago R, Miller SJ, et al. Exploring the use of a gamified intervention for encouraging physical activity in adolescents: a qualitative longitudinal study in Northern Ireland. BMJ Open. 2018;0:19663.

28. Coombes E, Jones A. Gamification of active travel to school: A pilot evaluation of the Beat the Street physical activity intervention. Health Place. 2016;39:62-9.

29. Shameli A, Althoff T, Saberi A, Leskovec J. How gamification affects physical activity: Large-scale analysis of walking challenges in a mobile application. In: 26th International World Wide Web Conference 2017, WWW 2017 Companion. New York, New York, USA: International World Wide Web Conferences Steering Committee; 2019. p. $455-63$.

30. Ahn SJ (Grace), Johnsen K, Ball C. Points-Based Reward Systems in Gamification Impact Children's Physical Activity Strategies and Psychological Needs. Health Educ. Behav. 2019;46:417-25.

31. Pope L, Garnett B, Dibble M. Lessons Learned Through the Implementation of an eHealth Physical Activity Gaming Intervention with High School Youth. Games Health J. 2018;7:136-42.

Received: 19/04/2021

Approved: 23/10/2021

Quote this article as:

Caputo EL, Feter N, Alt R, Leite JS, Rodrigues AN, Dumith SC, Silva MC. Increasing physical activity by Gamification among Brazilian high school students: a pilot study. Rev Bras Ativ Fis Saúde. 2021;26:e0230. DOI: 10.12820/rbafs.26e0230 